\title{
The Effect of Plant Growth Promoting Rhizobacteria on the Water-yield Relationship and Carotenoid Production of Processing Tomatoes
}

\author{
Tuan Anh Le \\ Vietnam Institute of Agricultural Engineering and Postharvest Technology \\ (VIAEP), Hanoi, Vietnam
}

\author{
Zoltán Pék, Sándor Takács ${ }^{1}$, and András Neményi \\ Institute of Horticulture, Faculty of Agriculture and Environmental Sciences, \\ Szent István University, Gödöllö, Hungary \\ Hussein G. Daood \\ Regional Knowledge Centre, Szent István University, Gödöllö, Hungary
}

\author{
Lajos Helyes \\ Institute of Horticulture, Faculty of Agriculture and Environmental Sciences, \\ Szent István University, Gödöllö, Hungary
}

Additional index words. irrigation, water use efficiency, SSC, carotenoids, ascorbic acid

\begin{abstract}
Open field experiments were conducted to investigate the effects of plant growth promoting rhizobacteria (PGPR) biofertilizer on processing tomato, grown under three different irrigation regimes. The field effectiveness of rhizobacteria inoculation on total biomass, yield, water use efficiency (WUE), carotenoid, and ascorbic acid production was examined in 2015 and 2016. The experimental design used was randomized block and the number of replications was four for each treatment. There were three different irrigation regimes: rain-fed control (RF), deficit water supply (WS50), and optimum water supply (WS100), which was delivered by drip irrigation in accordance with daily evapotranspiration (ETc). The test was performed on the Uno Rosso $F_{1}$ processing tomato hybrid. Red fruit were measured at harvest in August and high-performance liquid chromatography (HPLC) was used for analysis. We evaluated yield quantity and total carotenoids and their composition (lycopene and $\beta$-carotene) depending on water supplement in 2 years. The marketable yield varied between $14.7 \mathrm{t} \cdot \mathrm{ha}^{-1}$ and $126.9 \mathrm{t} \cdot \mathrm{ha}^{-1}$ depending on treatment. The average soluble solids content (SSC) of the treatments ranged from 3.0 to 8.4. The total carotenoid yields of the treatments ranged from 0.8 to $40.4 \mathrm{~kg} \cdot \mathrm{ha}^{-1}$ and the average lycopene yield of the treatments ranged from 0.6 to $34.1 \mathrm{~kg} \cdot \mathrm{ha}^{-1}$. The effect of PGPR treatment was clearly positive for harvested yield, but this effect only prevailed under irrigated conditions.
\end{abstract}

Nowadays, tomato is one of the most popular and important vegetable crops and is grown all over the world. European countries produced approximately 17.6 million tons of tomatoes in 2015, two-thirds of which was produced in Italy and Spain (11.2 million tons) (Eurostat, 2016). Almost all tomatoes

\footnotetext{
Received for publication 5 Mar. 2018. Accepted for publication 4 Apr. 2018.

We would like to thank the Stipendium Hungaricum, Research Center of Excellence 1476-4/2016/ FEKUT. This research was supported by the Higher Education Institutional Excellence Program awarded by the Ministry of Human Capacities within the framework of water-related researches of Szent István University. The publication was supported by the EFOP-3.6.3.-VEKOP-16.-2017-00008 project. The project is co-financed by the European Union and the European Social Fund.

${ }^{1}$ Corresponding author. E-mail: takacs.sandor@ mkk.szie.hu.
}

are consumed as raw commodities, with a quarter traded or directly processed into multifood products. In 2016, processing tomato production amounted to $38 \mathrm{Mt}$ worldwide and $10.6 \mathrm{Mt}$ in Europe (World Processing Tomato Council, 2017). Tomato is available year-round and provides significant health benefits. Fresh and processing tomato quality is affected by the interactions between varieties; environmental factors such as light, temperature, and water supply; and the composition of the nutrient solution and crop management (Dorais, 2007). Irrigation and the available water supply had a strong consequence on both the yield and the quality of processing tomato (Helyes et al., 2014).

In 2015, FAO reported that the amount of water used for agriculture accounted for $70 \%$ of all freshwater use in the world, mostly through irrigation. This is essential for food production since irrigation reduces drought risk and increases crop diversification, thereby also improving rural incomes. Irrigated land in agriculture makes up $\approx 20 \%$ but contributed to $40 \%$ of global food production (FAO, 2015). Processing tomato requires $400-800 \mathrm{~mm}$ of water from transplanting to harvest (Battilani et al., 2012). Drip irrigation is very efficient in saving water itself, but its efficiency can be increased by applying deficit irrigation (DI) in the field (Selim et al., 2012). Although this irrigation method causes water stress to plants, if the yield reduction is lower than the benefit derived from the water savings or from quality improvement, the lower yield becomes less important (Johnstone et al., 2005; Pék et al., 2017). The effects of DI vary year by year and affect crops differently; it is also influenced by soil (Helyes and Varga, 1994). The most common water deficit applied is $50 \%$ of ETc (Bakr et al., 2017), but other rates can be used as well (Patanè et al., 2014). Other techniques include the application of different DI rates in different vegetative stages (Kuşçu et al., 2014a; Nangare et al., 2016) or simply ending irrigation for the duration of various phenological stages (Johnstone et al., 2005; Kuşçu et al., 2014a; Lei et al., 2009). Water use efficiency is the ratio between yield and water in processing tomato and in other plants (Battilani et al., 2009). In this way, WUE can be considered a relative constant for a given crop under a given climate (Patanè et al., 2011). WUE is a very useful index for demonstrating the efficiency of water in plant production (Patané and Saita, 2015), which may contribute to saving irrigation water and thus to the preservation of this ever more restricted resource (Parry et al., 2005).

Plant growth promoting rhizobacteria have many beneficial effects on the soil environment: they enrich all kinds of microand macronutrients via nitrogen fixation and are responsible for phosphate and potassium solubilization or mineralization (Adesemoye et al., 2008). They involve various biotic activities of the soil ecosystem to make it dynamic for nutrient turnover and sustainable for crop production (Bhardwaj et al., 2014). Singh et al. (2011) reported applying biofertilizers as seed or soil inoculants, leading microorganisms to multiply and participate in nutrient cycling, which benefited crop productivity. In other research, PGPR has significantly increased marketable yield, reducing the fertilizer demand in lettuce (Sahin et al., 2015), broccoli (Yildirim et al., 2011), and tomato (Adesemoye et al., 2009). Other researchers found that PGPR is a useful tool for enhancing phytochemicals in tomato (Sabin et al., 2017) especially under stressful conditions (Ruzzi and Aroca, 2015).

The PGPR biofertilizer Phylazonit from Phylazonit Ltd. (Nyíregyháza, Hungary) can be used for many horticultural plant cultures. It has the following bacterial composition: Pseudomonas putida, Azotobacter chroococcum, Bacillus circulans, and Bacillus megaterium 
with germ number: $10^{9}$ cell $\mathrm{cm}^{-3}$ (Balla Kovács, 2010; Gajdos et al., 2009). Previously, it was found that when applied in wheat, corn, and cucumber in a climate chamber, Phylazonit significantly increased total root length, biomass production, and nutrient uptake (Gajdos et al., 2009). According to another researcher, Phylazonit increased the extractable $\mathrm{NO}_{3}{ }^{-}$in sandy soil, decreased the effect of wheat straw (high $\mathrm{C} / \mathrm{N}$ ratio), and helped in the decomposition of wheat straw and caused a significantly higher amount of organic-N (Balla Kovács, 2010). When Phylazonit was applied to maize, it led to a significant rise in the bacteria count compared with the control and to improvements in soil properties (Makádi et al., 2007).

The aim of this study was to establish the effects of PGPR Phylazonit on processing tomato Uno Rosso $F_{1}$ under three different irrigation regimes. Plants treated with PGPR at the time of sowing were evaluated for total biomass, yield, fruit phytonutrient production, and WUE.

\section{Materials and Methods}

Plant material. Open field experiments were conducted in 2015 and 2016 on two locations of the Institute of Horticulture's farm at the Szent István University, Gödöllö, Hungary; N47.594292, E19,359758 (Location 1) and N47.577380, E19.379573 (Location 2). The experiment involved the processing tomato hybrid Uno Rosso $F_{1}$ (United Genetics Seeds Co., Hollister, CA) and was performed in two consecutive years, 2015 and 2016. In the 2015 experiment at Location 1, the experimental field consisted of brown forest soil composed of sand and sandy clay mixture sandy loam; its texture consisted of $69 \%$ sand, $22 \%$ silt, and $9 \%$ clay; it had a $1.57 \mathrm{~g} \cdot \mathrm{cm}^{-3}$ bulk density and $19 \%$ field capacity; and was neutral in $\mathrm{pH}$, free from salinity $\left(0.16 \mathrm{dS} \cdot \mathrm{m}^{-1}\right)$, and low in organic carbon: $\mathrm{NO}_{3}{ }^{-} \mathrm{N}\left(5 \mathrm{~g} \cdot \mathrm{kg}^{-1}\right), \mathrm{P}_{2} \mathrm{O}_{5}$ $\left(15 \mathrm{~g} \cdot \mathrm{kg}^{-1}\right)$, and $\mathrm{K}_{2} \mathrm{O}\left(35 \mathrm{~g} \cdot \mathrm{kg}^{-1}\right)$. The transplantation date was 11 May and the harvest date was 18 Aug. In the 2016 experiment at Location 2, the soil was brown forest soil, which was loamy in texture (41\% sand, 47.5 silt, and $11.5 \%$ clay) and had a bulk density of $1.49 \mathrm{~g} \cdot \mathrm{cm}^{-3}$ and a $25 \%$ field capacity; it was free from salinity $\left(0.212 \mathrm{dS} \cdot \mathrm{m}^{-1}\right)$ and was low in organic matter, consisting of $\mathrm{NO}_{3}{ }^{-} \mathrm{N}$ $\left(8.6 \mathrm{~g} \cdot \mathrm{kg}^{-1}\right), \mathrm{P}_{2} \mathrm{O}_{5}\left(8 \mathrm{~g} \cdot \mathrm{kg}^{-1}\right)$, and $\mathrm{K}_{2} \mathrm{O}(56.7$ $\left.\mathrm{g} \cdot \mathrm{kg}^{-1}\right)$. Sowing was carried out on $13 \mathrm{Apr}$. in a greenhouse using Klasmann TS3 substrate in plastic trays. The experimental design was a randomized, complete block with four replications. Seedlings were arranged in double (twin) rows with a distance of $1.6 \mathrm{~m}$ between bed centers, $0.4 \mathrm{~m}$ in between the twin rows, and $0.2 \mathrm{~m}$ between the plants. Seedlings were planted out 4 weeks after sowing. The date of transplantation was 17 May and the harvest date was 28 Aug.

$P G P R$ and irrigation treatments. Immediately after sowing, plastic trays were either inoculated with a $1 \%$ liquid solution of Phylazonit (PGPR) or not (Control). The stock solution is a mixture of $P$. putida, A. chroococcum, B. circulans, and B. megaterium produced by Agrova Ltd. (Hungary, Nyíregyháza). Seedlings were inoculated with $1 \%$ Phylazonit $\mathrm{MC}^{\circledR}$ and the same solution was applied again with a drip-irrigation system (10 L stock solution per $1 \mathrm{~m}^{3}$ water) after planting out.

Temperature and precipitation were recorded six times per hour using a Campbell 21X Datalogger meteorological station (Campbell Scientific, Inc., Logan, UT). The daily amount of irrigation demand was calculated with the use of potential ETc and the crop coefficient $\left(K_{\mathrm{c}}\right)$ using CROPWAT 8.0 software (Kuo and Liu, 2003).

There were two different irrigation regimes (WS), based on ETc: ETc $\times K_{\mathrm{c}}$, meaning WS100, and half of this, $0.5 \times \mathrm{ETc} \times K_{\mathrm{c}}$; DI (WS50) was compared with an unirrigated, RF. The crop coefficient $K_{\mathrm{c}}$ ranged between 0.4 and 0.7 from transplanting to crop establishment; between 0.7 and 1.1 from crop establishment to the beginning of flowering; between 1.1 and 0.8 from the beginning of flowering to the beginning of fruit set; and between 0.8 and 0.6 from the beginning of fruit set to full maturity of the first and second truss fruit (Doorenbos and Pruitt, 1977).

In the 2015 experiment, irrigation was used to supply the plants with optimum amounts of water in the first 8 weeks of the seedling stage. The different irrigation treatments

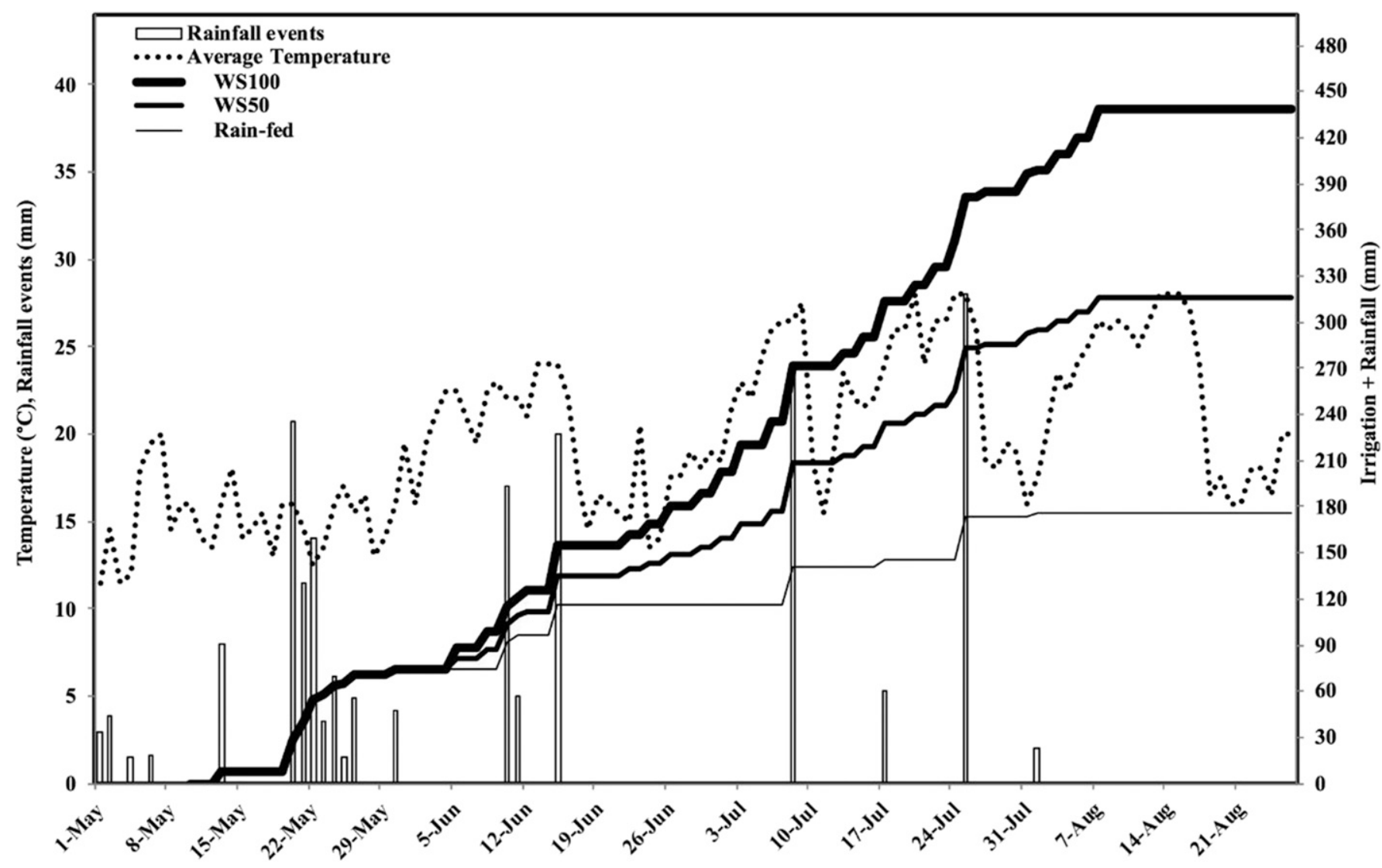

Fig. 1. Meteorological and irrigation data during the 2015 tomato vegetation period. 
started in the first week of June. In 2015, the recorded precipitation amounted to $175.6 \mathrm{~mm}$, which did not cover crop demand, therefore control plants (RF) suffered from drought during the growing season. The optimum (WS100) and deficit (WS50) supply involved irrigation amounts of 438.1 and $316.2 \mathrm{~mm}$ in total, respectively (Fig. 1).

The 2016 season differed significantly from 2015, as irrigation was started 5 weeks after transplantation because of rainy weather (Fig. 2). The average temperature was $20.6{ }^{\circ} \mathrm{C}$ during the season. There was some heavy rain in the middle of July and throughout the growing season, so the total precipitation amount was $315 \mathrm{~mm}$ for plants in the RF. The optimal irrigation and DI involved the application of $526.6 \mathrm{~mm}$ and $428 \mathrm{~mm}$ of irrigation water, respectively, including rain (Fig. 2).

At the time of harvest, we measured the weight of total biomass, then, we separated the marketable and nonmarketable fruit and measured the yield. Water use efficiency $\left(\mathrm{kg} \cdot \mathrm{m}^{-3}\right)$ was calculated as the ratio of marketable yield on a fresh weight basis at harvest $\left(\mathrm{FW}, \mathrm{t} \cdot \mathrm{ha}^{-1}\right)$ and total water used $\left(\mathrm{ET}, \mathrm{m}^{3} \cdot \mathrm{ha}^{-1}\right)$, as measured by water balance (Patanè et al., 2014).

Analysis of carotenoids, ascorbic acid, and SSC. Carotenoids extraction was done according to the method of Daood et al. (2014).
Ascorbic acid was extracted from $5 \mathrm{~g}$ of well-homogenized tomato by crushing in a crucible mortar and shaking for $15 \mathrm{~min}$ with $3 \%$ metaphosphoric acid solution. The mixture was filtered through a filter paper and purified by a $45-\mu \mathrm{m}$ nylon syringe filter before injection on to the HPLC column.

A Chromaster liquid chromatograph in (Hitachi, Japan) consisting of a Model 5110 Gradient pump, a Model 5210 auto sample, and a Model 5430 photodiode array detector was used. Operation and data processing were performed by EZChrom Elite software.

The separation of carotenoids was done on cross-linked C-18, $3-\mu \mathrm{m}, 150 \times 4.6 \mathrm{~mm}$ column, using gradient elution of water in acetone as described in the literature (Daood et al., 2014).

As for ascorbic acid, separation was performed on $\mathrm{C}-18,240 \times 4.6 \mathrm{~mm}, 5-\mu \mathrm{m}$ column under ion-pair chromatographic conditions optimized and validated by Daood et al. (1994). Ascorbic acid was identified using standard material (Sigma-Aldrich, Budapest, Hungary), from which stock and working solutions were prepared for getting the calibration curve.

Soluble solids content was estimated using Brix refractometry with a Krüss DR20195 Digital Refractometer (Krüss Optronic, Hamburg, Germany).

Statistical analysis. The software IBM SPSS version 23.0 for Windows (IBM Hungary,
Budapest, Hungary) was used for data analysis. The effect of Phylazonit, irrigation regimes, and their interaction was determined with two-way analysis of variance. Means $(n=4)$ with different letters are significantly different at $(P<0.05)$ as determined with a Tukey's Studentized range test.

\section{Results and Discussion}

The experiment in the 2015 growing season. The effect of irrigation on yield and the main ingredients of processing tomato fruit depend on the weather, especially on temperature and precipitation conditions during the growing season (Helyes and Varga, 1994). The average temperature was $20{ }^{\circ} \mathrm{C}$ and it paired with low precipitation, which resulted in a drought for processing tomato in 2015, as usual in Hungary (Fig. 1).

Irrigation had a great positive effect on marketable yield (384\% and $465 \%$ ) and total biomass (228\% and $284 \%$ ) production, compared with the RF. PGPR increased yield in the irrigated treatments only (Fig. 3A). PGPR treatment combined with better water supply resulted in additional significant growth of yield but not in the RF. Total biomass increased by more than $30 \%\left(120.6 \mathrm{t} \cdot \mathrm{ha}^{-1}\right)$ compared with its control, and the marketable yield reached the highest value of 93.8 t. ha ${ }^{-1}$ (37\% higher) in the WS100 treatment.

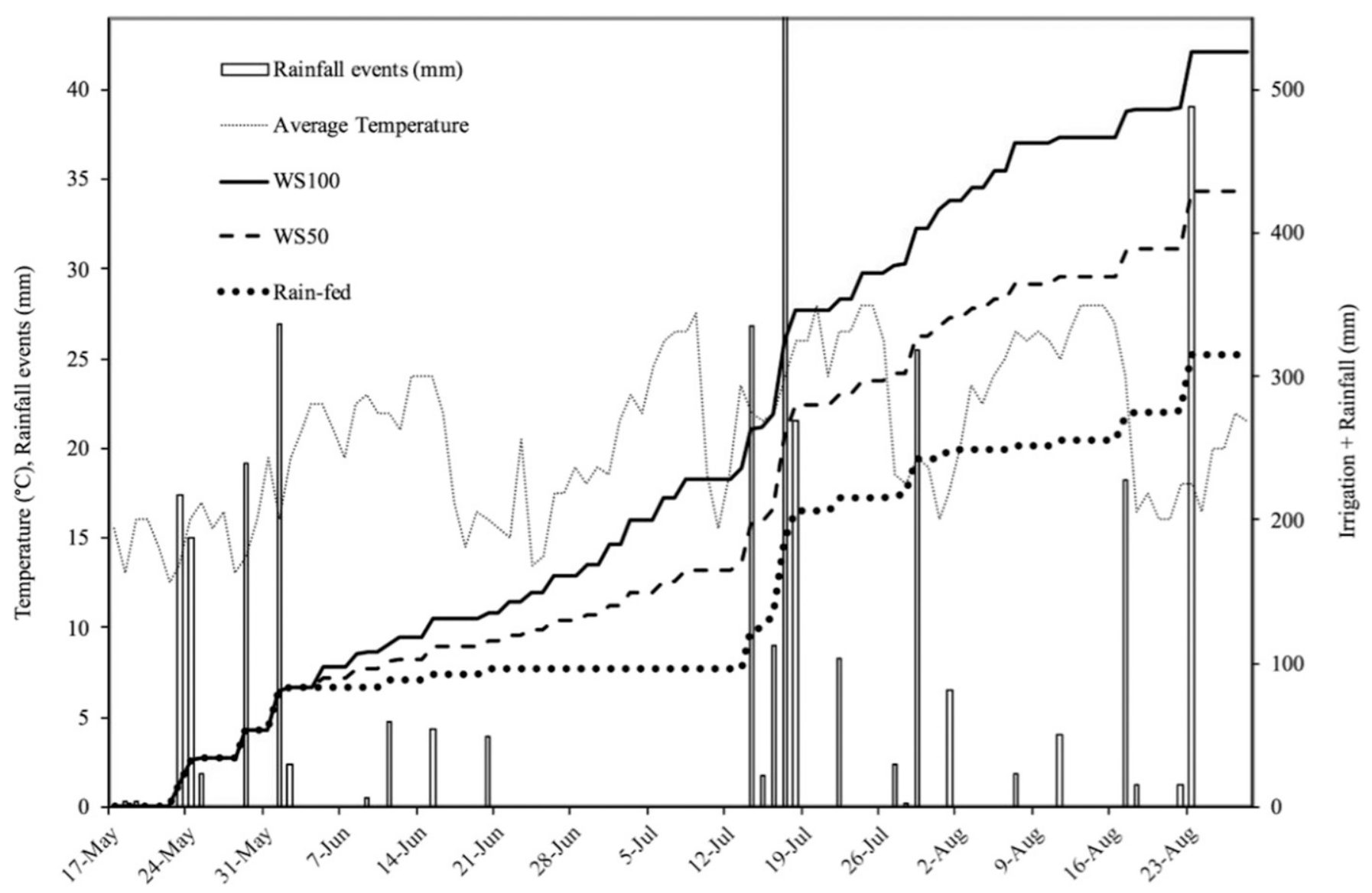

Fig. 2. Meteorological data during tomato vegetation in 2016 from May to August. 
With DI (WS50), the PGPR treatment increased the total biomass by $32 \%\left(98.0 \mathrm{t} \cdot \mathrm{ha}^{-1}\right)$ and marketable yield by $28 \%\left(72.6 \mathrm{t} \cdot \mathrm{ha}^{-1}\right)$ (Fig. 3B).

Irrigation gave a higher marketable yield, and control plants showed significant yield loss (Fig. 4A) in both years, which is in agreement with previous studies of processing tomato (Helyes et al., 2014; Pék et al., 2015). The PGPR treatment produced a significantly higher yield compared with controls only in the irrigated plots. This effect could be realized through the inhomogeneity of the soil moisture distribution resulting from drip irrigation (Selim et al., 2012) and enhancing soil nutrient mineralization to improve bacterial growth (Wang et al., 2017).

WUE is a useful index to demonstrate the role of water in plant production (Battilani et al., 2009). It may allow irrigation water to be saved, contributing to the preservation of this limited resource (Parry et al., 2005). DI produced the best WUE results $\left(32 \mathrm{~kg} \cdot \mathrm{m}^{-3}\right)$, which are significantly $(P<0.05)$ higher than in the other two water-supplied plots, by $12 \%$ and $22 \%$ respectively, in 2015 . The PGPR treatment resulted in significantly $(P<0.001)$ higher WUE in both deficit and optimum irrigation. WUE achieved a maximum of 32 $\mathrm{kg} \cdot \mathrm{m}^{-3}$ in WS50, which is an increase of $32 \%$ compared with the respective control (Fig. 5). Under optimal irrigation, the PGPR treatment increased WUE by $30 \%$, which is a good result in a temperate climate. In the combination of treatments, PGPR could increase WUE only in irrigated plots. DI usually increases WUE (Patanè et al., 2011, 2014), which effect was detected in 2015 only when combined with PGPR.

The most important quality parameter of processing tomato is SSC, which can be very high without irrigation (Helyes et al., 2014; Kuşçu et al., 2014a; Patanè and Cosentino, 2010). SSC was significantly higher in RF (7.8-8.4), and WS50 was also significantly higher (4.6-5.5) than WS100 (3.6-3.9) without PGPR, whereas PGPR treatments showed higher variability in irrigated plots (3.7-5.2) and lower variability in RF plots (7.3-7.9). Deficit and optimal irrigation reached higher marketable yields in the range of 53-93 t. ha ${ }^{-1}$; however, SSC decreased significantly. SSC and marketable yield had an adverse relationship. The higher the yield (more than $60 \mathrm{t} \cdot \mathrm{ha}^{-1}$ on average), the lower the obtained SSC (below 5.5 in the irrigated samples). Linear regressions showed different correlations between marketable yield and SSC affected by PGPR. According to the slope of linear regressions, PGPR treatments decreased SSC to a lesser extent than without PGPR (Fig. 6).

Total carotene production ranged from 0.8 to $12.1 \mathrm{~kg} \cdot \mathrm{ha}^{-1}$, which is almost a 15 -fold difference (Table 1). The value of total carotene production depended on the marketable yield in the RF, and we found a significant reduction in PGPR samples. However, irrigation regimes increased carotenoid yield. In WS100/PGPR, the treatment resulted in
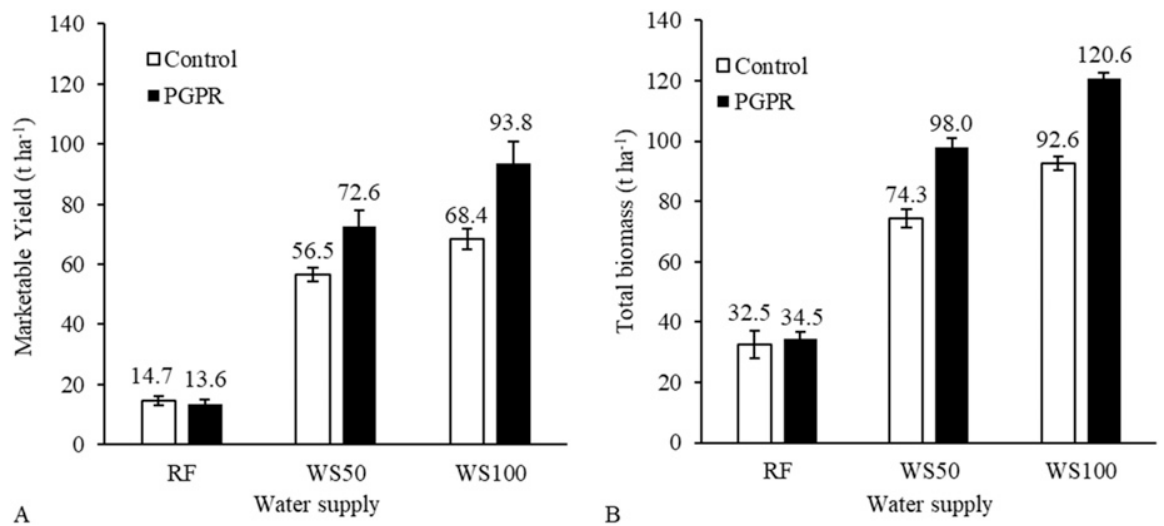

Fig. 3. Mean values of marketable yield (A) and total biomass (B) in different irrigation and plant growth promoting rhizobacteria (PGPR) treatment combinations in 2015. Vertical bars represent significant differences at $P<0.05(n=4)$.
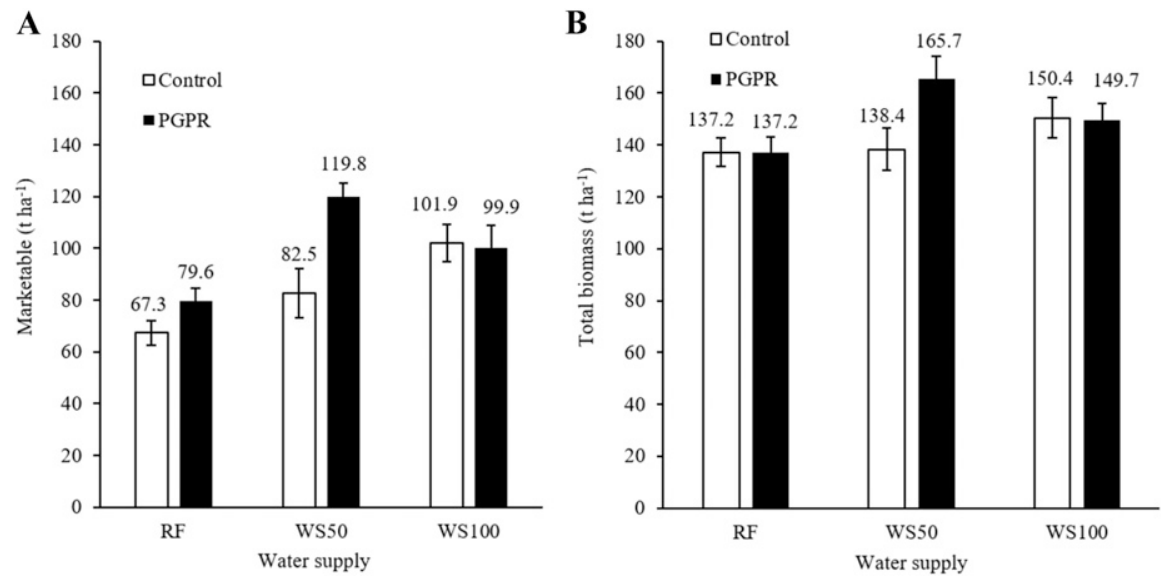

Fig. 4. Mean values of marketable yield (A) and total biomass (B) in different irrigation and plant growth promoting rhizobacteria (PGPR) treatment combinations in 2016. Vertical bars represent significant differences at $P<0.05(n=4)$.

a slight increase in lycopene $\left(4.7 \mathrm{~kg} \cdot \mathrm{ha}^{-1}\right)$, $\beta$-carotene $\left(0.227 \mathrm{~kg} \cdot \mathrm{ha}^{-1}\right)$ and total carotene $\left(7.2 \mathrm{~kg} \cdot \mathrm{ha}^{-1}\right)$ content. In WS50, there was a 2-fold difference in the total carotenoid yield between the control and PGPR, where the highest amount of total carotene was recorded $\left(12.1 \mathrm{~kg} \cdot \mathrm{ha}^{-1}\right)$. Lycopene and $\beta$-carotene increased by $126 \%$ and $148 \%$, respectively, in PGPR. By contrast, the amount of ascorbic acid in RF and WS50 had no significant difference between PGPR and the Control, but it reached the highest value $\left(23.47 \mathrm{~kg} \cdot \mathrm{ha}^{-1}\right)$ in WS100/PGPR samples with a significant difference in PGPR treatment.

The effect of PGPR on the measured components was not clear (Ruzzi and Aroca, 2015). In the case of total carotene, we detected a positive effect only in the DI treatment. The same positive effect was measured in the case of lycopene and $\beta$-carotene as well. Thus, carotene components were increased by PGPR (Ordookhani et al., 2010) the same way under moderate water scarcity (Bakr et al., 2017), and a slight change also appeared in the calculation of ascorbic acid yields. However, PGPR altered the lycopene and $\beta$-carotene yields negatively, along with the ascorbic acid yield.

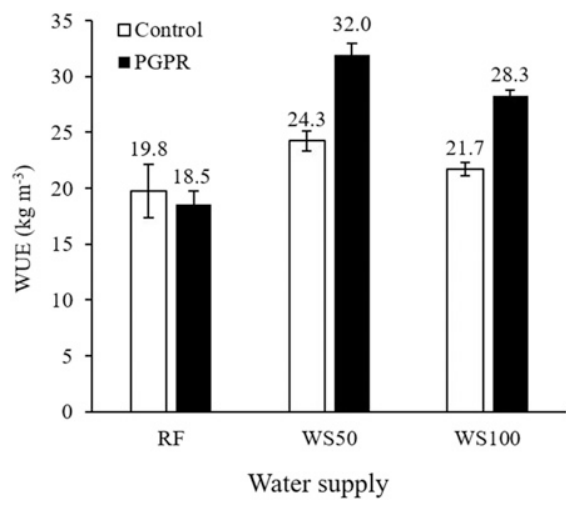

Fig. 5. Mean values of water use efficiency (WUE) in different irrigation and plant growth promoting rhizobacteria (PGPR) treatment combinations in 2015. Vertical bars represent significant differences at $P<0.05(n=4)$.

The reaction of the measured carotenoid components to the PGPR treatment was not significant when transpiration was not limited (WS100). It is important to note that the means of $\beta$-carotene were 0.152 and 0.227 $\mathrm{kg} \cdot \mathrm{ha}^{-1}$, respectively, in the optimal irrigated 
treatment. By contrast, more ascorbic acid was produced thanks to PGPR. The effect of water supply was clear in many cases. A deviation emerged between PGPR and its control in every water supply level in the case of lycopene, $\beta$-carotene, and ascorbic acid. But when we looked at total carotenoids, irrigation had no effect on the PGPR treatment when there was no water scarcity.

The experiment in the 2016 growing season. In the 2016 growing season, precipitation was almost twice that in the previous growing season, with lower seasonal temperatures and about sufficient water for processing tomato, which is unusual in Hungary (Pék et al., 2017). The differences were significant between the 2 years in the case of yields and carotenoids as well, which agrees with previous studies of processing tomato (Di Cesare et al., 2012; Helyes et al., 2012a, 2012b).

Deficit and optimal irrigation provided higher marketable yield in the range of 73$109 \mathrm{t} \cdot \mathrm{ha}^{-1}$ than RF (60-72 t.ha $\left.{ }^{-1}\right)$, so the mean values increased significantly from $67.3(\mathrm{RF})$ to 82.53 (WS50) and $101.86 \mathrm{t} \cdot \mathrm{ha}^{-1}$ (WS100) without PGPR. PGPR combined with irrigation showed a higher marketable yield (in the range of 90-127 th.ha ${ }^{-1}$ ), and the rhizobacteria treatment raised the aboveground total biomass by $4 \%, 20 \%$, and $1 \%$ in RF, WS50 and WS100, respectively (Fig. 4B). It raised the highest yield of marketable fruit to $119.8 \mathrm{t} \cdot \mathrm{ha}^{-1}$ and total biomass to $165.7 \mathrm{t} \cdot \mathrm{ha}^{-1}$ in WS50 (Fig. 4A). With respect to all water supply regimes (RF, WS50, and WS100), we did not find any difference in WUE of the control samples without PGPR. Better WUE was achieved in PGPR treatments, in RF $\left(26.9 \mathrm{~kg} \cdot \mathrm{m}^{-3}\right)$ and WS50 with the best use of water $\left(30.9 \mathrm{~kg} \cdot \mathrm{m}^{-3}\right)$, which were mostly the same as in the previous year (Fig. 7). WUE values higher than $10 \mathrm{~kg} \cdot \mathrm{m}^{-3}$ are usual in a Mediterranean climate (Giuliani et al., 2016; Kuşçu et al., 2014b; Patanè et al., 2011); values exceeded this in both years in case of irrigated samples.

SSC was significantly higher in the control (4.0-4.8) than in WS50 (3.6-3.8) and WS100 (3.0-4.7) without PGPR, whereas PGPR treatments showed higher variability (3.0-4.9) in all of the three irrigation regimes. Cut-off irrigation is a very useful tool to increase SSC in a Mediterranean climate (Mácua et al., 2003; Patanè and Cosentino, 2010) but not under Hungarian weather conditions because of the expected number of rainy weeks before harvest (Helyes et al., $2012 a, 2012 b)$. The negative effect of irrigation on yield and the positive effect of water deficit on SSC were also identified by other researchers (Patanè et al., 2014; Pék et al., 2017). PGPR did not affect marketable yield and SSC according to linear regression, but PGPR treated plants had a slightly higher SSC than control plants. According to correlation coefficients, marketable yield had a minimal effect on SSC with $\left(R^{2}=0.015\right)$ or without $\left(R^{2}=0.18\right)$ PGPR, which is due to rainy weather in 2016 (Fig. 8).

Increasing irrigation negatively affected and significantly reduced total carotenoid yield in marketable fruit from $18.8 \mathrm{~kg} \cdot \mathrm{ha}^{-1}$

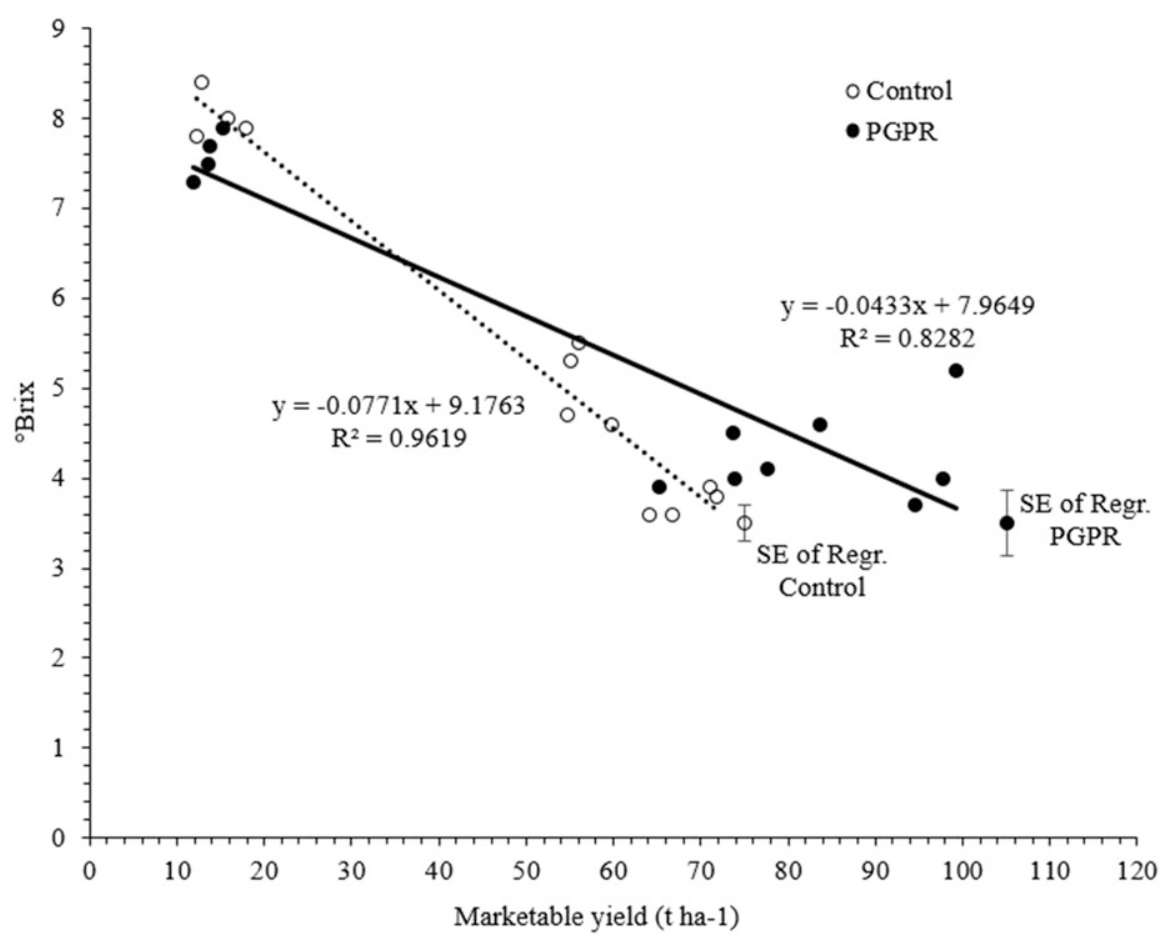

Fig. 6. Effect of plant growth promoting rhizobacteria (PGPR) on correlation between marketable yield and soluble solid content (Brix) in 2015. Vertical bars represent standard error of regressions $(n=12)$.

Table 1. Influence of water supply and plant growth promoting rhizobacteria (PGPR) on mean values of main and total carotenoids and ascorbic acid production in 2015.

\begin{tabular}{llcccr}
\hline Water supply & Treatments & $\begin{array}{c}\text { Total carotenoids } \\
\left(\mathrm{kg} \cdot \mathrm{ha}^{-1}\right)\end{array}$ & $\begin{array}{c}\text { Lycopene } \\
\left(\mathrm{kg} \cdot \mathrm{ha}^{-1}\right)\end{array}$ & $\begin{array}{c}\beta \text {-carotene } \\
\left(\mathrm{g} \cdot \mathrm{ha}^{-1}\right)\end{array}$ & $\begin{array}{r}\text { Ascorbic acid } \\
\left(\mathrm{kg} \cdot \mathrm{ha}^{-1}\right)\end{array}$ \\
\hline RF & Control & $2.01 \mathrm{~b} \pm 0.3$ & $1.48 \mathrm{~b} \pm 0.5$ & $39.8 \mathrm{~b} \pm 5.1$ & $4.89 \mathrm{a} \pm 1.3$ \\
& PGPR & $0.83 \mathrm{a} \pm 0.1$ & $0.62 \mathrm{a} \pm 0.1$ & $20.4 \mathrm{a} \pm 2.3$ & $4.42 \mathrm{a} \pm 0.4$ \\
WS50 & Control & $6.01 \mathrm{c} \pm 0.7$ & $4.07 \mathrm{c} \pm 0.5$ & $126.0 \mathrm{c} \pm 24.6$ & $16.14 \mathrm{~b} \pm 1.6$ \\
& PGPR & $12.09 \mathrm{~d} \pm 1.7$ & $9.20 \mathrm{~d} \pm 0.8$ & $312.8 \mathrm{~d} \pm 79.2$ & $16.15 \mathrm{bc} \pm 2.3$ \\
WS100 & Control & $6.45 \mathrm{c} \pm 1.4$ & $4.55 \mathrm{c} \pm 0.6$ & $152.1 \mathrm{c} \pm 36.0$ & $18.68 \mathrm{c} \pm 1.6$ \\
& PGPR & $7.21 \mathrm{c} \pm 1.2$ & $4.72 \mathrm{c} \pm 0.8$ & $227.3 \mathrm{~d} \pm 34.36$ & $23.47 \mathrm{~d} \pm 3.2$
\end{tabular}

Significant source of variation (ns $=$ not significant, $* P \leq 0.05, * * P \leq 0.01, * * * P \leq 0.001$ )

\begin{tabular}{|c|c|c|c|c|}
\hline PGPR & $* * *$ & $* * *$ & $* * *$ & $* * *$ \\
\hline Water supply (WS) & $* * *$ & $* * *$ & $* * *$ & $* * *$ \\
\hline $\mathrm{PGPR} \times \mathrm{WS}$ & $* * *$ & $* * *$ & $* * *$ & $* * *$ \\
\hline
\end{tabular}

Means with same letters in columns are not significantly different at $(P<0.05)$ as determined by analysis of variance and Tukey's Studentized range test (mean $\pm \mathrm{SD}, n=4)$.

in RF and $19.1 \mathrm{~kg} \cdot \mathrm{ha}^{-1}$ in WS50 to 13.5 $\mathrm{kg} \cdot \mathrm{ha}^{-1}$ in WS100. This negative trend was found to be even more evident in lycopene between RF and WS100. Irrigation regimes had no effect on $\beta$-carotene yield, and the ascorbic acid levels did not show a clear trend without PGPR. Moreover, besides the yield improvement in PGPR plants (Fig. 4), the PGPR treatment doubled the total carotenoid and lycopene production in irrigated plots (Table 2). The effect of PGPR on total carotene and lycopene was only apparent under irrigated conditions. However, positive effects were detected in the case of $\beta$-carotene in RF as well. PGPR affected ascorbic acid yields in RF and WS100, but the effect of irrigation was expressive. The effect of irrigation under WS100 was not significant in respect of total carotene and $\beta$-carotene either, but it was expressional in the WS50 treatment as it regards both total carotene and the measured carotene components. Total carotene, lycopene, and ascorbic

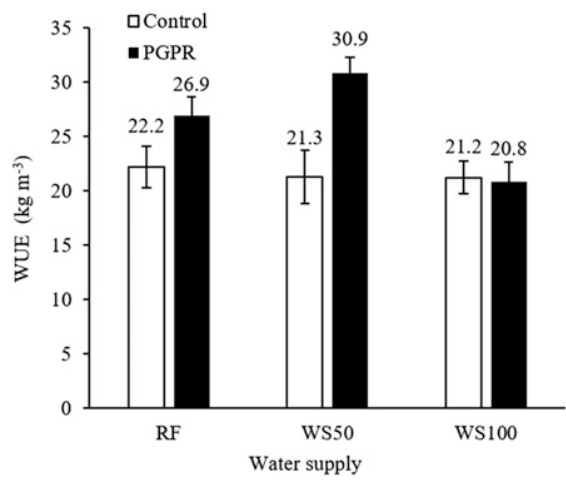

Fig. 7. Mean values of water use efficiency (WUE) in different irrigation and plant growth promoting rhizobacteria (PGPR) treatment combinations in 2016. Vertical bars represent significant differences at $P<0.05(n=4)$.

acid yields were affected by irrigation when additional water supply was not provided but $\beta$-carotene was not. 


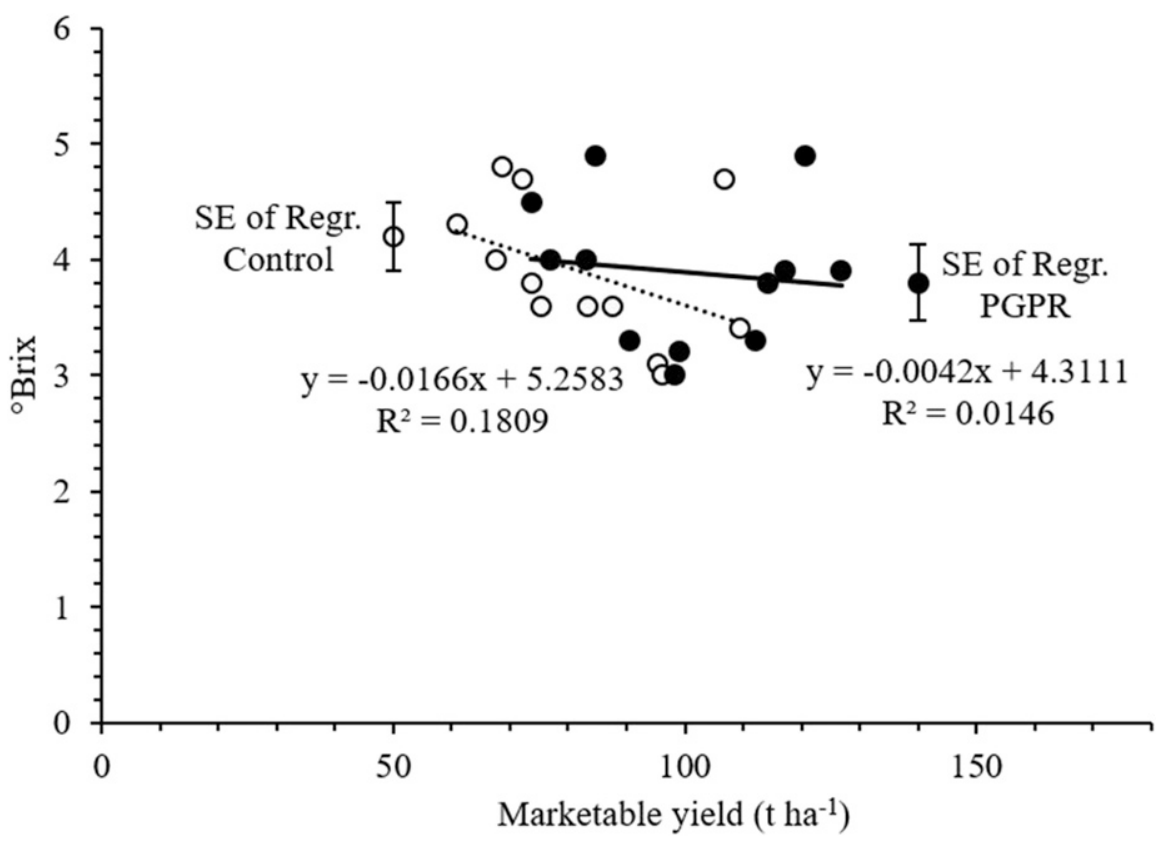

Fig. 8. Effect of plant growth promoting rhizobacteria (PGPR) on correlation between marketable yield and soluble solid content (Brix) in 2016. Open circles represent control and closed circles the PGPRtreated plants, vertical bars represent the standard error of regressions $(n=12)$.

Table 2. Influence of water supply and PGPR on mean values of main and total carotenoids and ascorbic acid production in 2016.

\begin{tabular}{|c|c|c|c|c|c|}
\hline Water supply & Treatments & $\begin{array}{l}\text { Total carotenoids } \\
\left(\mathrm{kg} \cdot \mathrm{ha}^{-1}\right)\end{array}$ & $\begin{array}{l}\text { Lycopene } \\
\left(\mathrm{kg} \cdot \mathrm{ha}^{-1}\right)\end{array}$ & $\begin{array}{c}\beta \text {-carotene } \\
\left(\mathrm{g} \cdot \mathrm{ha}^{-1}\right)\end{array}$ & $\begin{array}{c}\text { Ascorbic acid } \\
\left(\mathrm{kg} \cdot \mathrm{ha}^{-1}\right)\end{array}$ \\
\hline \multirow[t]{2}{*}{$\overline{\mathrm{RF}}$} & Control & $18.79 \mathrm{~b} \pm 1.4$ & $15.91 \mathrm{~b} \pm 1.2$ & $11.93 \mathrm{a} \pm 1.4$ & $20.52 \mathrm{a} \pm 1.3$ \\
\hline & PGPR & $18.01 \mathrm{~b} \pm 1.5$ & $15.24 b \pm 1.2$ & $12.78 \mathrm{ab} \pm 1.1$ & $25.78 b \pm 1.3$ \\
\hline \multirow[t]{2}{*}{ WS50 } & Control & $19.11 \mathrm{abc} \pm 4.4$ & $10.75 \mathrm{a} \pm 1.6$ & $12.67 \mathrm{ab} \pm 1.1$ & $36.50 \mathrm{~cd} \pm 5.4$ \\
\hline & PGPR & $40.39 \mathrm{~d} \pm 1.5$ & $34.11 \mathrm{~d} \pm 1.1$ & $20.78 \mathrm{c} \pm 2.1$ & $38.86 \mathrm{~cd} \pm 4.8$ \\
\hline \multirow[t]{2}{*}{ WS100 } & Control & $13.47 \mathrm{a} \pm 2.3$ & $10.74 \mathrm{a} \pm 2.0$ & $10.20 \mathrm{a} \pm 1.4$ & $32.89 \mathrm{c} \pm 2.8$ \\
\hline & PGPR & $25.33 \mathrm{c} \pm 2.6$ & $21.59 \mathrm{c} \pm 2.3$ & $15.67 b \pm 3.4$ & $43.94 \mathrm{~d} \pm 2.2$ \\
\hline \multicolumn{6}{|c|}{ Significant source of variation $(\mathrm{ns}=$ not significant, $* P \leq 0.05, * * P \leq 0.01, * * * P \leq 0.001)$} \\
\hline \multicolumn{2}{|l|}{ PGPR } & $* * *$ & $* * *$ & $* * *$ & *** \\
\hline \multicolumn{2}{|c|}{ Water supply (WS) } & $* * *$ & $* * *$ & $* * *$ & $* * *$ \\
\hline \multicolumn{2}{|l|}{$\mathrm{PGPR} \times \mathrm{WS}$} & $* *$ & $* *$ & $* *$ & * \\
\hline
\end{tabular}

Means with same letters in columns are not significantly different at $(P<0.05)$ as determined by analysis of variance and Tukey's Studentized range difference test (mean $\pm \mathrm{SD}, n=4)$.

The yield-enhancing effect of irrigation was clear when a water supply between 300 and $500 \mathrm{~mm}$ was provided. Marketable yield is limited below $200 \mathrm{~mm}$ (RF, 2015) and above $500 \mathrm{~mm}$ (WS100 2016). The effect of PGPR treatment was clearly positive for harvested yield, but this effect only prevailed under irrigated conditions. With a combination of different water supply and PGPR, acceptable yield was realized also between 300 and $500 \mathrm{~mm}$ of water. Below $200 \mathrm{~mm}$ (RF, 2015) and greater than $500 \mathrm{~mm}$ (WS100 2016), the amount of water supply PGPR treatment did not result in greater yield, and the same trend can be seen in WUE. Additional studies are needed to determine how the time of PGPR application and the amount of irrigation water can be optimized.

\section{Literature Cited}

Adesemoye, A.O., H.A. Torbert, and J.W. Kloepper. 2008. Enhanced plant nutrient use efficiency with PGPR and AMF in an integrated nutrient management system. Can. J. Microbiol. 54:876886.
Adesemoye, A.O., H.A. Torbert, and J.W. Kloepper. 2009. Plant growth-promoting rhizobacteria allow reduced application rates of chemical fertilizers. Microb. Ecol. 58:921-929.

Bakr, J., H.G. Daood, Z. Pék, L. Helyes, and K. Posta. 2017. Yield and quality of mycorrhized processing tomato under water scarcity. Appl. Ecol. Environ. Res. 15:401-413.

Balla Kovács, A. 2010. Effects of ammonium nitrate, wheat straw and Phylazonit MC bacterial fertilizer on the N supply of soil. Agrokem. Talajt. 59:185-194.

Battilani, A., H. Prieto, C. Argerich, C. Campillo, and V. Cantore. 2012. Tomato, p. 192-198. In: P. Steduto, T.C. Hsiao, E. Fereres, and D. Raes (eds.). Crop yield response to water FAO irrigation and drainage paper 66. Food and Agriculture Organization of the United Nations, Rome, Italy.

Battilani, A., D. Solimando, C.R. Jensen, F.L. Plauborg, M.N. Andersen, and L. Sandei. 2009. Water saving irrigation strategies for processing tomato. Acta Hort. 823:69-76.

Bhardwaj, R., P. Ohri, R. Kaur, A. Rattan, D. Kapoor, S. Bali, P. Kaur, A. Khajuria, and R. Singh. 2014 Gene Silencing, p. 209-228. In: P. Ahmad and S. Rasool (eds.). Emerging technologies and management of crop stress tolerance. Vol. 1. Elsevier Inc., San Diego, CA.

Daood, H.G., G. Bencze, G. Palotás, Z. Pék, A Sidikov, and L. Helyes. 2014. HPLC analysis of carotenoids from tomatoes using crosslinked C18 column and MS detection. J. Chromatogr. Sci. 52:985-991.

Daood, H.G., P.A. Biacs, M.A. Dakar, and F. Hajdu. 1994. Ion-pair chromatography and photodiode-array detection of vitamin $\mathrm{c}$ and organic acids. J. Chromatogr. Sci. 32:481-487.

Di Cesare, L.F., C. Migliori, V. Ferrari, M. Parisi, G. Campanelli, V. Candido, and D. Perrone. 2012. Effects of irrigation-fertilization and irrigation-mycorrhization on the alimentary and nutraceutical properties of tomatoes, p. 207-232. In: T.S. Lee (ed.). Irrigation systems and practices in challenging environments. Intech, Rijeka, Croatia.

Doorenbos, J. and W.O. Pruitt. 1977. Guidelines for predicting crop water requirements. Food Agr. Organ. United Nations 154.

Dorais, M. 2007. Organic production of vegetables: State of the art and challenges. Can. J. Plant Sci. 87:1055-1066.

Eurostat. 2016. Agriculture, forestry and fishery statistics - 2015 edition. European Union, Luxembourg.

FAO. 2015. FAO statistical pocketbook 2015. FAO, Rome, Italy.

Gajdos, É., S. Veres, N. Bákonyi, B. Tóth, É. Bódi, M. Marozsán, and L. Lévai. 2009. Role of biofertilizers in plant nutrition. More Sustain. Agr. New Fertil. Fertil. Mgt. 16-22.

Giuliani, M.M., G. Gatta, E. Nardella, and E. Tarantino. 2016. Water saving strategies assessment on processing tomato cultivated in Mediterranean region. Ital. J. Agron. 11:69-76.

Helyes, L., A. Bőcs, A. Lugasi, and Z. Pék. 2012a. Tomato antioxidants and yield as affected by different water supply. Acta Hort. 936:213-218.

Helyes, L., A. Lugasi, H.G. Daood, and Z. Pék. 2014. The simultaneous effect of water supply and genotype on yield quantity, antioxidants content and composition of processing tomatoes. Not. Bot. Hort. Agrobot. Cluj-Napoca 42:143-149.

Helyes, L., A. Lugasi, and Z. Pék. 2012b. Effect of irrigation on processing tomato yield and antioxidant components. Turk. J. Agr. For. 36:702709.

Helyes, L. and G. Varga. 1994. Irrigation demand of tomato according to the results of three decades. Acta Hort. 376:323-328.

Johnstone, P.R., T.K. Hartz, M. LeStrange, J.J. Nunez, and E.M. Miyao. 2005. Managing fruit soluble solids with late-season deficit irrigation in drip-irrigated processing tomato production. HortScience 40:1857-1861.

Kuo, S.F. and C.W. Liu. 2003. Simulation and optimization model for irrigation planning and management. Hydrol. Processes 17:3141-3159.

Kuşçu, H., A. Turhan, and A.O. Demir. 2014a. The response of processing tomato to deficit irrigation at various phenological stages in a sub-humid environment. Agr. Water Mgt. 133:92-103.

Kuşçu, H., A. Turhan, N. Ozmen, P. Aydinol, and A.O. Demir. 2014b. Optimizing levels of water and nitrogen applied through drip irrigation for yield, quality, and water productivity of processing tomato (Lycopersicon esculentum Mill.). Hort. Environ. Biotechnol. 55:103-114.

Lei, S., Q. Yunzhou, J. Fengchao, S. Changhai, Y. Chao, L. Yuxin, L. Mengyu, and D. Baodi. 2009. Physiological mechanism contributing to efficient use of water in field tomato under different irrigation. Plant Soil Environ. 55:128133. 
Mácua, J.I., I. Lahoz, A. Arzoz, and J. Garnica. 2003. The influence of irrigation cut-off time on the yield and quality of processing tomatoes. Acta Hort. 613:151-153.

Makádi, M., A. Tomócsik, V. Orosz, J. Lengyel, B. Bíró, and Á. Márton. 2007. Effect of digestate and Phylazonit MC on the yield of silage maize and the biological activity of the soil. Agrokem. Talajt. 56:367-378.

Nangare, D.D., Y. Singh, P.S. Kumar, and P.S. Minhas. 2016. Growth, fruit yield and quality of tomato (Lycopersicon esculentum Mill.) as affected by deficit irrigation regulated on phenological basis. Agr. Water Mgt. 171:73-79.

Ordookhani, K., K. Khavazi, A. Moezzi, and F. Rejali. 2010. Influence of PGPR and AMF on antioxidant activity, iycopene and potassium contents in tomato. Afr. J. Agr. Res. 5:1108-1116.

Parry, M.A.J., J. Flexas, and H. Medrano. 2005. Prospects for crop production under drought: Research priorities and future directions. Ann. Appl. Biol. 147:211-226.

Patanè, C. and S.L. Cosentino. 2010. Effects of soil water deficit on yield and quality of processing tomato under a Mediterranean climate. Agr. Water Mgt. 97:131-138.

Patanè, C., S. La Rosa, A. Pellegrino, O. Sortino, and A. Saita. 2014. Water productivity and yield response factor in two cultivars of processing tomato as affected by deficit irrigation under semi-arid climate conditions. Acta Hort. 1038:449-454.

Patanè, C. and A. Saita. 2015. Biomass, fruit yield, water productivity and quality response of processing tomato to plant density and deficit irrigation under a semi-arid Mediterranean climate. Crop Pasture Sci. 66:224-234.

Patanè, C., S. Tringali, and O. Sortino. 2011. Effects of deficit irrigation on biomass, yield, water productivity and fruit quality of processing tomato under semi-arid Mediterranean climate conditions. Scientia Hort. 129:590-596.

Pék, Z., H.G. Daood, A. Neményi, L. Helyes, and P. Szuvandzsiev. 2017. Seasonal and irrigation effect on yield parameters and soluble solids content of processing cherry tomato. Acta Hort. 1159:45-49.

Pék, Z., P. Szuvandzsiev, A. Neményi, and L. Helyes. 2015. Effect of season and irrigation on yield parameters and soluble solids content of processing cherry tomato. Acta Hort. 1081: 197-202.

Ruzzi, M. and R. Aroca. 2015. Plant growthpromoting rhizobacteria act as biostimulants in horticulture. Scientia Hort. 196:124-134.

Sabin, F., A. Tehmina, H. Riaz, and A. Basharat. 2017. PGPR mediated bio-fortification of tomato fruit metabolites with nutritional and pharmacological importance. Pakistan J. Biotechnol. 14:17-21.
Sahin, U., M. Ekinci, F.M. Kiziloglu, E. Yildirim, M. Turan, R. Kotan, and S. Ors. 2015. Ameliorative effects of plant growth promoting bacteria on water-yield relationships, growth, and nutrient uptake of lettuce plants under different irrigation levels. HortScience 50:13791386.

Selim, T., R. Berndtsson, M. Persson, M. Somaida, M. El-Kiki, Y. Hamed, A. Mirdan, and Q. Zhou. 2012. Influence of geometric design of alternate partial root-zone subsurface drip irrigation (APRSDI) with brackish water on soil moisture and salinity distribution. Agr. Water Mgt. 103:182-190.

Singh, J.S., V.C. Pandey, and D.P. Singh. 2011. Efficient soil microorganisms: A new dimension for sustainable agriculture and environmental development. Agr. Ecosyst. Environ. 140:339-353.

Wang, J., W. Niu, M. Zhang, and Y. Li. 2017. Effect of alternate partial root-zone drip irrigation on soil bacterial communities and tomato yield. Appl. Soil Ecol. 119:250-259.

World Processing Tomato Council. 2017. World production estimate of tomatoes for processing. WPTC, Monteaux, France.

Yildirim, E., H. Karlidag, M. Turan, A. Dursun, and F. Goktepe. 2011. Promotion of broccoli by plant growth promoting rhizobacteria. HortScience 46:932-936. 